\title{
Goal Setting as an Antecedent of Teachers Performance in Public Secondary Schools
}

\author{
Calisto Ochieng Odindo
}

Jaramogi Oginga Odinga

Arvinlucy Onditi

Fronica Monari

University of Science and Technology

\begin{abstract}
This study aims at establishing the effect of goal setting on the performance of public secondary school teachers in Kisumu Central Sub-County. The study was guided by goal setting theory and adopted descriptive survey design. The study also used both primary and secondary data. The primary data was collected through close ended questionnaires and interview while the secondary data was collected through document analysis. The data collected was used to analyze both descriptive and inferential statistics. The study found out that there is a positive correlation between goal setting and the performance of public secondary school teachers. The study also established that there is a significant positive relationship between goal setting and teachers' performance. The study therefore concluded that there is a positive relationship between goal setting and performance of public secondary school teachers in Kisumu Central Sub-County.
\end{abstract}

\subsection{Introduction}

Sauers \& Bass (1990) defined goal setting as a formal program of setting numerical or quantitative performance targets for individual employee in order to increase his/her motivation and performance at workplace. Goal setting is often used by managers at workplace to control attitude and behavior of employees because it enables them to pull their efforts in one direction. Scholars have argued that goal setting should be focused on the specific and challenging targets that are achievable for it to be an effective strategy in influencing employee performance (Locke, Smith, Erez, Chah \& Schaffer, 1994). Therefore, goal setting guarantees the employee success in his or her job to the extent of attaining the set targets. This is so because it strongly influences employee behavior that positively contributes to changes in his or her performance (Bandura \& Cervone, 1983; Latham et al, 1975; Latham et al, 2013).

Goal setting is one of the suitable strategies that have been used by employers to motivate their employees to perform because research findings have linked improved employee performance to goal setting. Therefore employees should be encouraged to set goals at the beginning of every performance cycle (Locke, 2003). Goal setting in this study has been explored in terms of its motivational impact towards improving the quality of teaching and its ability to assist teachers remains efficient when teaching (TPAD, 2020). According to TSC (2020), the first step in performance management is target setting. Teachers and their supervisor (head of department or deputy principal) are therefore required to have a target setting meeting where they share understanding of what they aim at; discuss the competency areas and set deadlines as per school calendar of activities.

This article aims at assisting teachers understand the importance of goal setting in enhancing their performance. A lot of research on goal setting in education sector has focused on students' academic performance but little literature exists on impact of goal setting on performance of public secondary school teachers. The findings will help advance and contribute knowledge on the theory of goal setting and its effect on the employee performance.

\subsection{Statement of the Problem}

Goal setting in organizations enhances performance of employees by influencing their cognitive processing that stimulates the development of specific strategies to realize the organization's targets (Locke \& Latham, 2013). Research has shown that when employees set specific and challenging goals, their performances increase significantly compared to those employees who are committed to just doing their best (Locke et at 1994).

Since 2016 teachers have been setting targets at individual or departmental levels as per the requirements of performance management but their performances have continued to be perceived by the members of the public and the stakeholders in the education sector to be very low. 
Therefore it is difficult to determine whether the goals set are specific and challenging and that teachers are committed towards achieving them or teachers merely set them for the sake of fulfilling appraisal requirement. This study therefore aims at establishing impact of goal setting on improving the teacher performance.

\subsection{Theoretical Literature and Empirical Literature Review}

\subsubsection{Theoretical Literature Review}

The study was guided by goal setting theory which states that the source of employee motivation is in his/her desires and intentions to reach a set goal. According to Locke \& Latham (2006) a goal is the action or task's aim that an employee consciously desires to obtain or achieve. This theory argues that teams or individuals who have not achieved their desired goals in their current performance will be motivated to change their strategies or improve their effort or the dissatisfaction with the current performance hence set new goals so that they can better their results (Locke \& Latham, 2006). This theory forecast that employees will direct their efforts towards achieving the goals they have set hence impacting on their performance. For goals to be achieved, Locke and Latham theory of goal setting gives importance to conditions like acceptance and commitment to the goal, specificity of the goal, goal difficulty and feedback on the progress (O’Neil \& Drillings, 1994). Goal setting theory mechanism also impacts on the performance since the mechanisms increase the employee motivation to achieve the set goals. These mechanisms according to Latham (2004) include effective strategies, persistence, energized employees and direct attention to the goal.

The relevance of this theory to the current study is in line with the works of Lathan \& Locke (1979) that highlights four mechanisms that connect goals to performance outcomes. First, goals direct attention to priorities that is when specific goals are set by teachers it drives their attention to priorities of achieving the goals. Second, they stimulate effort, in other words when sets of goals are attached to specific reward system it stimulates workers to work better and effectively. Third, they challenge teachers to bring their knowledge and skills to bear to increase their chances of performing better. Fourth, the more challenging the goal, the more the teachers will draw on their full stock of skills.

\subsubsection{Empirical Literature Review}

\subsubsection{Goal Setting and Employee Performance}

A study by Camp (2017) on goal setting as teacher development practice in higher institutions established that teachers favored teaching strategy goals as compared to content and course management goals. The researcher relied on goal setting theory to guide the study. The study relied purely on qualitative study design where data was collected through full group discussion involving the 12 volunteers. The study concluded that to realize significant progress, teachers needed to be committed to the goals they have set as commitment leads to motivation. The study relied only on qualitative data.

According to Janes \& Dobson (2016) study established that improved learning and teaching is experienced when it becomes habit of the organization to use goals as part of the performance appraisal. The study used qualitative design and employed interviews and document analysis to collect data and was guided by goal setting theory. The study concluded that the teachers' performance is strengthened by performance goals only when policy makers, teachers and school leaders are working together as a team.

Amponsah (2015) study on goal setting as a motivation to teachers that was carried out to establish how senior high school teachers in Eastern Region of Ghana were motivated by the goal setting practices adopted the Maslow's theory of hierarchy of needs and the goal setting theory to guide the study. The quantitative research design and survey were employed. The study found out that intrinsic and extrinsic factors of motivation influence goal setting and that goal setting directs the teachers' attention to the achievement of goals set and if not achieved they put extra effort after resetting the goals. The study concluded that goal setting practices enable teachers to teach effectively and efficiently. The current study used both quantitative and qualitative data to provide in-depth information on the effect of goal setting on the teacher performance.

According to Mukonambi (2016) study on the effect of participative goal setting on employee performance established that goal setting improves employee performance. The goal setting theory was adopted to guide the study. The descriptive survey research design was used and data was collected through questionnaire and interview.

The sample size used in the study was 216 employees obtained through stratified sampling (middle level management), simple random sampling (low cadre officers) and purposive sampling (top management). The study concluded that participative goals setting led to improved performance however joint goal setting was not provided for in performance management.

\subsection{Research Methodology}

\subsubsection{Research Design and Sampling}


The study adopted descriptive survey design. The target population of the study was 112 teachers employed in 7 Sub-County secondary schools in Kisumu Central Sub-County. The study used a sample size of 88 teachers who were determined by the Yamane (1967) formula from their target population of 112 teachers as shown:

$$
\text { Sample Size } \mathrm{n}=\frac{N}{1+N(e)^{2}}
$$

Where; $\mathrm{n}$ is sample size Equation 3.0

$\mathrm{N}$ is population size (teachers)

$\mathrm{e}$ is the margin error

$$
\begin{aligned}
& =\frac{112}{1+112(0.05)^{2}} \\
& \mathrm{n}=88 \text { respondents }
\end{aligned}
$$

The sample size for the study was 88 respondents (7 deputy principals and 81 classroom teachers). In this study, the purposive sampling technique was used to select the Deputy Principals whereas teachers were sampled through stratified sampling (according to departments) and simple random sampling (from every department). The final respondents who participated in the study were arrived at through a lottery method.

\subsubsection{Data Collection and Analysis}

The primary data from the respondents was collected by use of close ended questionnaires to collect quantitative data and interview developed based on the objectives of the study to collect qualitative data. Secondary data was collected through document analysis of past performance of teachers. The researcher adopted drop and pick method to collect data from respondents. This allowed the respondents to conveniently respond to the questions.

Data was analyzed using both descriptive (mode, mean, frequency distribution \& percentages) and inferential statistics (correlation and regression) of the data collected and was presented in form of tables and graphs. The raw qualitative data collected through interview were analyzed by content analysis.

\subsubsection{Reliability and Validity of Research Instruments}

To determine reliability and validity of the research instruments, a pilot study was carried out in 2 Sub-County schools in Kisumu East Sub-County. These 2 schools had the same characteristics as the study schools. The reliability of the study research instruments was tested using Cronbach's alpha and a reliability alpha of 0.71 was obtained against the benchmark of 0.70 . Validity was determined by use of content and face validity. The questionnaires were pre-tested through test-retest method and a validity index of 0.81 making them valid.

The regression model used in the study was:

$\mathrm{Y}=\beta_{0}+\beta_{1} \chi_{1}+\varepsilon \ldots \ldots \ldots \ldots \ldots \ldots$ Equation 3.0

$\mathbf{Y}=$ Teacher performance as measured by the school means score, quality grades attained in KCSE and cocurricular ranking

$\mathbf{B}_{\mathbf{0}}=$ Constant

$\mathbf{B}_{1}=$ coefficient of independent variable (goal setting)

$\mathbf{X}_{\mathbf{1}}=$ goal setting as measured by attendance rate, syllabus coverage and time management.

$\boldsymbol{\varepsilon}=$ the error term

\subsection{Findings and Discussions}

The objective of the study was to determine the effect of goal setting on the performance of public secondary school teachers in Kisumu Central Sub-County.

The study evaluated the respondents' level of agreement with various statements on goal setting using a 5 point Likert scale where 1 - strongly agree; 2 - agree; 3 - neutral; 4 - disagree; and 5 - strongly disagree. From these results a mean of 1 indicate that respondents strongly agreed with the statement, a mean of 2 indicate that respondents agreed with the statement, a mean of 3 indicate that the respondents are neutral about the statement, a mean of 4 indicate that respondents disagreed with the statement and a mean of 5 indicate that the respondents strongly disagreed with the statement. The standard deviation gives the variation of the response from the mean. The smaller the standard deviation the better the results as it indicates that the response were not far from the mean response. The study findings were as illustrated in Table 4.1; 
Table 4.1 Respondents level of agreement with statement on goal setting

\begin{tabular}{|c|c|c|c|c|c|c|c|}
\hline Statements & S.A & $\mathbf{A}$ & $\mathbf{N}$ & D & S.D & Mean & $\begin{array}{l}\text { Std } \\
\text { Deviation }\end{array}$ \\
\hline $\begin{array}{l}\text { Setting teaching goals have } \\
\text { helped me improve my teaching. }\end{array}$ & $\begin{array}{l}37 \\
47.4 \%\end{array}$ & $\begin{array}{l}33 \\
42.3 \%\end{array}$ & $\begin{array}{l}5 \\
6.4 \%\end{array}$ & $\begin{array}{l}2 \\
2.6 \%\end{array}$ & $\begin{array}{ll}1 \\
1.3 \%\end{array}$ & 1.68 & 0.814 \\
\hline $\begin{array}{l}\text { Working with colleagues in the } \\
\text { department on goal setting has } \\
\text { helped me improve my teaching }\end{array}$ & 35 & $\begin{array}{l}33 \\
42.3 \%\end{array}$ & $\begin{array}{l}5 \\
6.4 \%\end{array}$ & 4 & $\begin{array}{l}1 \\
1.3 \%\end{array}$ & 1.76 & 0.885 \\
\hline $\begin{array}{l}\text { Goal setting has enhanced } \\
\text { completion of syllabus on time }\end{array}$ & $\begin{array}{l}32 \\
41.0 \%\end{array}$ & $\begin{array}{l}29 \\
37.2 \%\end{array}$ & $\begin{array}{l}15 \\
19.2 \%\end{array}$ & $\begin{array}{l}2 \\
2.6 \%\end{array}$ & $\begin{array}{l}0 \\
0 \%\end{array}$ & 1.83 & 0.828 \\
\hline $\begin{array}{l}\text { Goal setting has contributed to } \\
\text { higher attendance rate of } \\
\text { teachers }\end{array}$ & $20.6 \%$ & $\begin{array}{l}39 \\
50.0 \%\end{array}$ & $\begin{array}{l}15 \\
19.2 \%\end{array}$ & $\begin{array}{ll}3 \\
3.8 \%\end{array}$ & $\begin{array}{l}1 \\
1.3 \%\end{array}$ & 2.05 & 0.851 \\
\hline $\begin{array}{l}\text { Teachers are committed to the } \\
\text { goals they have set }\end{array}$ & $\begin{array}{l}24 \\
30.8 \%\end{array}$ & $\begin{array}{l}38 \\
48.7 \%\end{array}$ & $\begin{array}{l}15 \\
19.2 \%\end{array}$ & $\begin{array}{l}0 \\
0 \%\end{array}$ & $\begin{array}{l}1 \\
1.3 \%\end{array}$ & 1.92 & 0.786 \\
\hline $\begin{array}{l}\text { Goal setting by teachers has } \\
\text { improved their performance }\end{array}$ & $\begin{array}{l}23 \\
29.5 \%\end{array}$ & $\begin{array}{l}36 \\
46.2 \%\end{array}$ & $\begin{array}{l}16 \\
20.5 \%\end{array}$ & $\begin{array}{l}3 \\
3.8 \%\end{array}$ & $\begin{array}{l}0 \\
0 \% \\
\end{array}$ & 1.99 & 0.814 \\
\hline Average Mean & & & & & & 1.87 & 0.830 \\
\hline $\mathrm{N}$ & 78 & 78 & 78 & 78 & 78 & 78 & 78 \\
\hline
\end{tabular}

\section{Source: Researcher (2020)}

Table 4.1 shows that majority of the respondents, 70 respondents $(89.7 \%)$, agreed that they set teaching goals that have helped them improve their teaching; majority of the respondents, $68(87.2 \%)$, agreed that working with colleagues in the department when setting goals has helped them improve their teaching; majority of the respondents, $61(78 \%)$, agreed that by setting goals they were able to complete syllabus in time; majority of the respondents, $59(75.6 \%)$, agreed that goal setting has contributed to their higher attendance rate; majority of the respondents, 62 respondents $(79.5 \%)$ agreed that they were committed to the goals they have set and; majority of the respondents, 59 respondents $(75.7 \%)$ agreed with the statement that goal setting has improved their performance. The average mean response of 1.87 implied that goal setting has a positive effect on performance of teachers in public secondary school teachers in Kisumu Central Sub-County.

Interview results indicated that teachers participated in goal setting. Deputy Principals confirmed that teachers set individual and departmental goals and then they are encouraged to work towards achieving those targets. This helps them to remain focused. It was also noted that individual teacher performance at different schools was still very low even with the specific and challenging goals that teachers set.

TSC (2019) report indicated that there was an improvement in school and class attendance by teachers. This improvement has been credited to effective performance management with clear, specific and challenging targets that required every teacher to be committed towards achieving them.

The findings are in line with Janes et al (2016) findings that performance of both the employee and the management is weak when the goals are set and used in an environment that lacks common understanding and language and that improved performance is experienced when the management makes it a habit of using goals as part of the performance appraisal. They further noted that performance appraisal is strengthened by performance goals only when the supervisors and employees work together as a team. The results further concur with those of Amponsah (2015) and Mukonambi (2016) whose study findings established that goals setting contribute to improved employee performance.

\subsubsection{Correlation between performance appraisal and employee performance}

The study sought to establish the effect of performance appraisal on performance of public sector employees a case of public secondary school teachers in schools in Kenya. 
Table 4.2 Pearson Correlation

\section{Correlations}

\begin{tabular}{lll|l} 
& & Teacher Performance & Goal Setting \\
\hline Teacher Performance & Pearson Correlation & 1 & $.240^{*}$ \\
\cline { 2 - 4 } & Sig. (1-tailed) & & .017 \\
\hline & $\mathrm{N}$ & 78 & 78 \\
\hline Goal Setting & Pearson Correlation & $.240^{*}$ & 1 \\
\cline { 2 - 4 } & Sig. (1-tailed) & .017 & \\
\hline & $\mathrm{N}$ & 78 & 78 \\
\hline
\end{tabular}

*. Correlation is significant at the 0.05 level (1-tailed).

\section{Source: Researcher (2020)}

Table 4.2 shows that there is $r$ value of 0.240 which is a weak positive correlation between goal setting and teacher performance. The result indicates that an increase in goal setting have a positive effect on the teacher performance. The results obtained further indicate that there is a significant positive correlation between goal setting and teachers' performance with a correlation coefficient of 0.240 and $\mathrm{P}$ value $\mathrm{p}<0.05$. Findings indicate that there is a significant positive correlation between goal setting and teacher performance and therefore the variable was statistically significant.

\subsubsection{Regression analysis}

The regression analysis was conducted to establish the relationship between goal setting and employee performance. Table 4.3 shows the model summary.

\section{Table 4.2 Model Summary}

Model Summary
\begin{tabular}{ll|l|l|l} 
Model R & R Square & Adjusted R Square & Std. Error of the Estimate \\
\hline 1 & $.240^{\mathrm{a}}$ & .057 & .045 & .52294 \\
\hline
\end{tabular}

a. Predictors: (Constant), goal setting

\section{Source: Researcher (2020)}

According to the Table 4.3, R-square was 0.057 which means $5.70 \%$ variation in teachers' performance was due to goal setting while the remaining $94.30 \%$ of variation in teachers' performance was explained by other factors not considered in the current study.

$\mathrm{R}$ value is the correlation coefficient which shows the relationship between the study variables, from the findings in Table 4.3, there was a weak positive relationship between the study variables as indicated by $r$ value of $0.240^{\mathrm{a}}$ this was so because the value tends to be closer to 0 (zero) than 1 . The difference between Adjusted R Square and $\mathrm{R}$ Square is 0.045 which shows that the independent variable was precise. Further the results indicate that variables in the regression model and its fitness can be relied up to $4.5 \%$ (adjusted $R^{2}=0.045$ ) in predicting the performance of public secondary school teachers in Kisumu

Central Sub-County and this prediction is statistically significant $\left(\mathrm{p}=0.035^{\mathrm{b}}<0.05 ; \mathrm{F}=4.635\right)$. Therefore teachers can use these variables in the model with substituted coefficients $\left(\mathrm{Y}=1.386+0.199 \chi_{1}\right)$.

Table 4.4 ANOVA (Analysis of Variance)

\section{ANOVA $^{\mathrm{a}}$}

\begin{tabular}{|c|c|c|c|c|c|c|}
\hline \multicolumn{2}{|c|}{ Model } & Sum of Squares & $\mathrm{df}$ & Mean Square & $\mathrm{F}$ & Sig. \\
\hline 1 & Regression & 1.268 & 1 & 1.268 & 4.635 & $.035^{\mathrm{b}}$ \\
\hline & Residual & 20.784 & 76 & 273 & & \\
\hline & Total & 22.051 & 77 & & & \\
\hline
\end{tabular}

a. Dependent Variable: teacher performance

b. Predictors: (Constant), goal setting

Source: Researcher (2020) 
From the Table 4.4, F test significant with a $\mathrm{p}$ value $=0.005$ which was less than the standard $\mathrm{p}$ of 0.05 meant that the model was significant. From ANOVA, since p value was 0.035 and was less than p value of 0.05 and therefore goal setting influenced the performance of public secondary school teachers in Kisumu Central Sub-County. Further the results confirm that variable in the regression model $\beta_{0}+\beta_{1} \chi_{1}+\varepsilon$ and its fitness can be relied up to $4.5 \%$ (adjusted $\mathrm{R}^{2}=0.045$ ) in predicting the performance of teachers in public secondary schools in Kisumu Central Sub-County and this prediction is statistically significant $\left(\mathrm{p}=0.035^{\mathrm{b}}<0.05 ; \mathrm{F}=4.635\right)$.

\section{Table 4.5 Regression Coefficient}

\begin{tabular}{|c|c|c|c|c|c|c|c|}
\hline \multicolumn{8}{|l|}{ Coefficients $^{\mathrm{a}}$} \\
\hline \multirow[b]{2}{*}{ Model } & \multicolumn{2}{|c|}{$\begin{array}{l}\text { Unstandardized } \\
\text { Coefficients }\end{array}$} & \multirow{2}{*}{$\begin{array}{l}\text { Standardized } \\
\text { Coefficients } \\
\text { Beta }\end{array}$} & \multirow[b]{2}{*}{$\mathrm{T}$} & \multirow[b]{2}{*}{ Sig. } & \multicolumn{2}{|c|}{$\begin{array}{l}95.0 \% \text { Confidence } \\
\text { Interval for B }\end{array}$} \\
\hline & B & Std. Error & & & & $\begin{array}{l}\text { Lower } \\
\text { Bound }\end{array}$ & $\begin{array}{l}\text { Upper } \\
\text { Bound }\end{array}$ \\
\hline 1 (Constant) & 1.386 & .233 & & 5.940 & .000 & .921 & 1.851 \\
\hline Goal setting & .199 & .092 & .240 & 2.153 & .035 & .015 & .382 \\
\hline
\end{tabular}

a. Dependent Variable: Teacher performance

Source: Researcher (2020)

Based on the regression results shown on Table 4.5 the regression model

$\mathrm{Y}=1.386+0.199 \chi_{1}$

Equation 3.0

From the regression equation shown, taking the predictor (independent) variable (goal setting) constant at zero the teachers' performance is 1.386 . From the results, a unit increase in goal setting there would be 0.199 increases in the performance of public secondary school teachers. At significance level of 0.05 , goal setting had a significance level of 0.035 . Goal setting had a significance level less than 0.05 hence made a significant contribution in predicting the outcome (teachers' performance).

\subsubsection{Discussions}

The results indicate that teachers in public secondary schools agreed that goal setting programs influence their performance. The results further revealed that there is $r$ value of 0.240 which is a weak positive correlation between goal setting and employee performance as it tends to be closer to $r=0$, however an increase in goal setting will result in positive effect on teacher performance. The results also indicate that there is a significant positive relationship between goal setting and the performance of public secondary school teachers in Kisumu Central SubCounty with a correlation coefficient of 0.240 and $P$ value $p<0.05$. The findings are in line with Janes et al (2016) findings that performance of both the employee and the management is weak when the goals are set and used in an environment that lacks common understanding and language and that improved performance is experienced when the management makes it a habit of using goals as part of the performance appraisal.

They further noted that performance appraisal is strengthened by performance goals only when the supervisors and employees work together as a team. The results further concur with those of Amponsah (2015) and Mukonambi (2016) whose study findings established that goals setting contribute to improved employee performance.

\subsection{Study Conclusions}

The objective was to establish the effect of goal setting on performance of public secondary school teachers in Kisumu Central Sub-County. Based on the findings of the study, it can be concluded that there is a positive relationship between goal setting and teacher performance in public secondary schools in Kisumu Central SubCounty. The relationship was found to be statistically significant given that P-value was less than 0.05 .

\subsubsection{Study Recommendations}

Goal setting was found to positively affect the performance of public secondary schools, the deputy principals should create conducive environment that can facilitate goal setting. All the teaching staff should participate in goal setting as frequent as possible.

\section{References}

Amponsah, A. U. G. U. S. T. I. N. A. (2015). Goal setting as a motivation to teachers: A Study of Teachers of Second Cycle Schools in the New-Juaben and Yilo Krobo District of the Eastern Region (Doctoral dissertation, University of Ghana).

Bandura, A., \& Cervone, D. (1983). Self-evaluative and self-efficacy mechanisms governing the motivational effects of goal systems. Journal of personality and social psychology, 45(5), 1017. 
Camp, H. (2017). Goal Setting as Teacher Development Practice. International journal of teaching and learning in higher education, 29(1), 61-72.

Latham, G. P., \& Locke, E. A. (1979). Goal setting-A motivational technique that works. Organizational dynamics, 8(2), 68-80.

Locke, E. A., \& Latham, G. P. (2006). New directions in goal-setting theory. Current directions in psychological science, 15(5), 265-268.

Locke, E. A., \& Latham, G. P. (2013). Goal Setting Theory. In New Developments in Goal Setting and Task Performance (pp. 27-39). Routledge.

Locke, E. A., Smith, K. G., Erez, M., Chah, D. O., \& Schaffer, A. (1994). The effects of intra-individual goal conflict on performance. Journal of management, 20(1), 67-91.

Mukonambi, D. W. (2016). Participative goal setting effects on employee performance at the Kenya seed company, Kitale (Doctoral dissertation, Moi University).

O'Neil, H. F., \& Drillings, M. (Eds.). (2012). Motivation: Theory and research. Routledge.

Sauers, D. A., \& Bass, K. (1990). Sustaining the positive effects of goal setting: The positive influence of peer competition. Akron Business and Economic Review, 21(4), 30.

Seijts, G. H., Latham, G. P., Tasa, K., \& Latham, B. W. (2004). Goal setting and goal orientation: An integration of two different yet related literatures. Academy of management journal, 47(2), 227-239. 